\title{
Soybean Seed Phenol, Lignin, and Isoflavones and Sugars Composition Altered by Foliar Boron Application in Soybean under Water Stress
}

\author{
Nacer Bellaloui \\ Crop Genetics Research Unit, USDA-ARS, Stoneville, USA. \\ Email: nacer.bellaloui@ars.usda.gov \\ Received January $5^{\text {th }}, 2012$; revised February $23^{\text {rd }}, 2012$; accepted March $31^{\text {st }}, 2012$
}

\begin{abstract}
Previous research showed that foliar boron (B) application at flowering or seed-fill growth stages altered seed protein, oil, and fatty acids. The objective of this research was to investigate the effects of foliar B fertilizer on seed phenolics (phenol, lignin, and isoflavones) and sugars concentrations. A repeated greenhouse experiment was conducted on soybean $[(G l y c i n e \max (\mathrm{L}$.) Merr. $)]$ under watered and water-stressed conditions. Soybean plants were divided into different sets, and each set was subjected to one of the following treatments: $\mathrm{W}=$ plants were watered with no foliar $\mathrm{B}$; $\mathrm{WB}=$ plants were watered and received foliar B; WS = plants were water-stressed with no foliar B; WSB = plants were waterstressed and received foliar B. Foliar B was applied at rate of $0.45 \mathrm{~kg} / \mathrm{ha}$ twice at flowering and twice at seed-fill stages. The results showed that total phenol and lignin concentrations were higher in seed collected from water-stressed plants compared with those collected from watered plants whether B was applied or not. The higher total phenol and lignin concentration in seed collected of water-stressed plants may be due to B-deficiency in plant tissues. Application of B resulted in higher concentrations of total seed B and isoflavones under watered and water-stressed plants. Higher cell wall B was higher in water-stressed plants than in watered plants, having an opposite trend to total B. Application of B resulted in higher seed sucrose in watered and water-stressed plants, but raffinose and stachyose were significantly higher under water-stressed plants. The research demonstrated that foliar B fertilizer altered seed phenol, lignin, isoflavones, and sugars, suggesting that B involved in phenolics and sugar metabolism. The higher cell wall B in waterstressed plants than in watered plants supports previous research that B has mainly a structural role. The higher sucrose resulting from foliar B in watered plants is desirable as sucrose contributes to seed quality. The increase of raffinose and stachyose concentrations in seed of water-stressed plants is undesirable as raffinose, and especially stachyose may be involved in water stress/drought tolerance. The current knowledge would help soybean breeders select for higher phenolic compounds and desirable sugars for higher seed qualities under drought conditions.
\end{abstract}

Keywords: Boron Nutrition; Seed Lignin; Seed Phenolics; Isoflavones; Soybean

\section{Introduction}

Soybean is a major source for human food and livestock feed. Soybean seeds contain about $42 \%$ protein and $19.5 \%$ of oil [1], $33 \%$ carbohydrates [2,3], and essential minerals [4]. Soybean seeds contain saturated fatty acids, including palmitic acid (C16:0) (10\% to $12 \%)$ and stearic acid (C18:0) (2.2\% to $7.2 \%)$, and unsaturated fatty acids, including oleic acid (C18:1) (24\%), linoleic acid (C18:2) (54\%), and linolenic acid (C18:3) (8.0\%) [2,5]. One of the benefits of soybean seed is that it contains secondary natural metabolite compounds, including phenolic acid,

\footnotetext{
*Mention of trade names or commercial products in this publication is solely for the purpose of providing specific information and does not imply recommendation or endorsement by the US Department of Agriculture.
}

lignin, and isoflavones. These compounds are thought to have multi-health benefits for humans and plants. For example, isoflavones and phenolics are reported to have health benefits as antioxidants against heart disease and cancer [6-9].

Boron (B) is an essential nutrient for plant growth, development, and productivity $[10,11]$ and crop quality $[12,13]$. The role of $B$ in flower, fruit, and seed set $[14$, 15], seed quality and composition [16], and pollen tube growth [17] was previously reported. Boron requirements were higher during flowering and seed set, and $\mathrm{B}$ deficiency was shown even when B levels in soils were in the adequate range [12]. Recently, it was found that foliar B fertilizer improved seed protein and seed oleic fatty acid in soybean [16], seed yield and seed quality in al- 
falfa [12], and increased fruit set [18]. Boron deficiency reduces stomatal opening and transpiration [19], induces plasma membrane solute leakage [20], inhibits meristematic tissue development, resulting in growth inhibition [11] and maintenance of cell wall integrity [21]. Boron also plays a vital role in transport of carbohydrates, cell wall metabolism [22], permeability and stability of cell membranes, and phenol metabolism [11].

Phenolics, including lignin and isoflavones have beneficial effects against diseases when plants are attacked by pathogens [23-25]. Phenolics or polyphenols are synthesized through the shikimate phenylpropanoids flavonoids pathways, producing monomeric and polymeric phenols and polyphenols [26,27]. Phenolics such as benzoquinones (C6), phenolic acid (C6-C1), flavonoids and isoflavonoids (C6-C3-C6), and lignins (C6)n, (C6-C3-C6)n $[28,29]$ are essential for growth, reproduction, and protection of plants against biotic (fungus, bacteria, virus, and insect infection) or abiotic stresses such as drought and temperature. The mechanisms of how plants adapt to environmental changes to use phenols, isoflavones, and lignin are not understood, especially under drought conditions.

Isoflavones are a class of phenolics and synthesized through a branch of the phenylpropanoid pathway, and they belong to a group of compounds called phytoalexins that have an active role in disease resistance [23]. Isoflavones have antioxidant activities by protecting cells from oxidative damage and free radicals [30]. Free radicals are harmful to human health [31] because they oxidize biomolecules in the cell, leading to mutagenic changes, tissue damage, and cell death. Genistein, daidzein, and glycitein are the major soybean isoflavones. The phenylpropanoid pathway is also involved in the synthesis of other phenolic compounds such as tannins, lignins, lignans, anthocyanins, flavones, flavonols, and the soybean phytoalexins glyceollins, which are pterocarpans and possess antimicrobial activities [32]. Amino acid, L-phenylalanine, is the precursor in the pathway, and it is stripped of its amine group to produce cinnamic acid via the enzyme phenylalanine ammonia lyase (PAL). Then, cinnamate 4-hydroxylase $(\mathrm{C} 4 \mathrm{H})$ and 4-coumarate $\mathrm{CoA}$ ligase (4CL) convert cinnamic acid into $p$-coumaryol CoA. Chalcone synthase (CHS) is the first critical enzyme for flavonoid synthesis [33]. Chalcone isomerase (CHI) converts chalcones to flavanones, and chalcone reductase (CHR) is responsible for daidzein and glycitein formation. Isoflavone synthase (IFS) catalyzes a 2, 3 aryl ring migration of flavanones to their corresponding isoflavones [34-36]. In the soybean genome, IFS is present in two copies, IFS1 and IFS2 differing in a few amino acids, and they responsible for converting naringenin to genistein and liquiritigenin to daidzein.
Drought effects on growth, photosynthesis, transpiration [37], and crop productivity [38] were previously reported. However, very little is known about the mechanisms controlling seed phenolic compounds production under stress environment such as drought or water stress. Previous research on lignin reported that water deficit results in a reduction in the amount of ferulic acid, increase of p-coumaric and caffeic acids in the xylem sap [39], decrease in anionic peroxidase activity, increased cationic peroxidase activity, increase of free lignin precursors in the xylem sap [39], and increase in the expression of two genes involved in the biosynthesis of lignin: cinnamoyl-CoA reductase 1 and 2 [40]. The alteration in these processes leads to the increase of lignin deposition and cell wall stiffness, and reduced cell wall extensibility and cell wall expansion. This is an adaptive mechanism of plants to improve the availability of water, minerals, sugars, and maintain minimum growth by reducing crop yield. It was reported that at the early stages of water stress, plants increased root growth, leading to the induction of proteins involved in morphogenesis such as actin, $\alpha$-tubulin, Ran guanosine triphosphatase (GTP-ase), and carbon and nitrogen metabolism such as isoforms of triose-phosphate isomerase, malate dehydrogenase, $\alpha$ mannosidase, uridine diphosphate (UDP)-sugar pyrophosphorylase, nicotinamide adenine dinucleotide phosphate (NADP)-malic enzymes, phosphoglucomutase and UDP glucose-6-phosphate dehydrogenase). However, in the final stage of water stress, reduction in root growth and induction of lignin biosynthesis occur by increased expression of caffeoyl CoA 3-O-methyltransferase (CCo$A O M T$ ) and a large number of isoenzymes including class III peroxidases.

It was observed at the early stage of water stress $(0$ $14 \mathrm{~d}$ ), the activity of some enzymes involved in lignin biosynthesis increased. Among these enzymes were phenylalanine ammonia lyase (PAL) and ascorbate peroxidase. This activity decreased gradually as the period of stress was prolonged. On the other hand, other enzymes such as guaiacol peroxidase, coniferyl alcohol peroxidase and syringaldazine peroxidase exhibited greater activity during the final stages of stress (14 - $28 \mathrm{~d})$ [41].

In spite of the role of phenolics in cell structure and integrity against diseases, its stability under environmental conditions such as water stress and their relationships with B is still not understood. Therefore, the objective of this research was to investigate the effects of foliar B fertilizer and water stress on the concentration of seed phenol, lignin, isoflavones. Since B has been thought to have a physiological and biochemical role in phenolics and carbohydrates metabolism [11], and have a structural role in cell wall $[11,16]$, seed cell wall boron 
and seed sugars were also investigated.

\section{Materials and Methods}

\subsection{Growth Conditions}

A greenhouse experiment was repeated twice (experiment 1 and experiment 2) in 2010 during the soybean growing season (March-August). Seed of soybean cultivar AG 4903RR were germinated in flat trays in vermiculite. Uniform size seedlings at about V1 stage were transplanted into $9.45 \mathrm{~L}$ size pots filled with field soil. The soil was a Dundee silt loam (fine-silty, mixed, active, thermic Typic Endoqualfs) with $\mathrm{pH} 6.3,1.1 \%$ organic matter, a cation exchange capacity of $15 \mathrm{cmol} / \mathrm{kg}$, and soil textural fractions of $26 \%$ sand, $56 \%$ silt, and $18 \%$ clay, average B concentration of $0.72 \mathrm{mg} \cdot \mathrm{kg}^{-1}$, and contained an abundant native population of B. japonicum. To introduce water stress, soil in pots were weighed and then saturated with dionized water and left to drain and weighed again to obtain the water field capacity as measured by soil water sensors inserted in pots [16]. Soil water potential was measured daily using Soil Moisture Meter (WaterMark Company, Inc., Wisconsin, USA). Water stressed plants were kept between -90 and -100 $\mathrm{kPa}$. This represented a moderate to severe water stress level for soybean under greenhouse conditions. Watered plants were kept between -15 to $-20 \mathrm{kPa}$ (this was considered field capacity for the control plants) [16]. Half of the plants from each B treatment was watered (W), and the other half was water-stressed (WS). Treatments were watered plants with no foliar B (W), watered plants with foliar B (WB), water stress plants with no foliar B (WS), and water stress plants with foliar B (WSB). Boron, as boric acid, of a rate of $0.45 \mathrm{~kg} \cdot \mathrm{ha}^{-1}$ was foliar applied using hand sprayer, and measures to avoid boron drift to the control plants were taken [16]. Boron was applied at flowering stage (R1 - R2) at R1 and at R2 and at seed-fill stage (R5 - R6) at R5 and at R6 [42], or not applied (control). Mature seed were collected at harvest maturity (R8 stage). Plants were considered fully matured when they reached R8 according to Fehr et al. (1971). Treatments were arranged in a split plot design with irrigation as a main block and B treatment as sub-plot. Four replicates were used for each treatment in each experiment. Each pot with four individual plants was considered one replicate Greenhouse conditions were about $34^{\circ} \mathrm{C} \pm 9^{\circ} \mathrm{C}$ during the day and about $28^{\circ} \mathrm{C} \pm 7^{\circ} \mathrm{C}$ at night with a photosynthetic photon flux density (PPFD) of about $800-2300$ $\mu \mathrm{mol} \cdot \mathrm{m}^{-2} \cdot \mathrm{s}^{-1}$, as measured by Quantum Meter (Spectrum Technology, Inc., Illinois, USA). The range of light intensity reflects a bright, sunny, or cloudy day. The source of lighting in the greenhouse was a mixture of natural light, incandescent bulb light $(60 \mathrm{~W})$, and cool white fluorescent $(250 \mathrm{~W})$. Experiment 1 and Experiment 2 were conducted in different greenhouse bays. To be consistent with the normal photoperiod for soybean growth and to avoid differences in the day-length between the two experiments, the two experiments were conducted simultaneously at the same time and during the normal growing season (from April to September) of the Early Soybean Production System in the midsouth USA.

\subsection{Boron Determination}

Boron concentration was measured according to others $[12,16]$ using the Azomethine- $\mathrm{H}$ method [43]. A $1 \mathrm{~g}$ sample of dry seed was ashed at $500^{\circ} \mathrm{C}$ for $8 \mathrm{~h}$, extracted with $20 \mathrm{ml}$ of $2 \mathrm{M} \mathrm{HCl}$ at $90^{\circ} \mathrm{C}$ for 10 minutes, and then the extract was filtered. The samples were then transferred to plastic vials. A sample of $2 \mathrm{ml}$ was added to 4 $\mathrm{mL}$ of buffer solution (containing $25 \%$ ammonium acetate, $1.5 \%$ EDTA, and $12.5 \%$ acetic acid) and $4 \mathrm{~mL}$ of azomethine- $\mathrm{H}$ solution containing $0.45 \%$ azomethine- $\mathrm{H}$ and $1 \%$ of ascorbic acid [44]. To measure boron concentrations, samples were then read at $420 \mathrm{~nm}$ after 45 minutes using a Beckman Coulter DU 800 spectrophotometer (Fullerton, California).

Boron concentration in cell wall was measured according to others $[16,21]$. Seed samples were homogenized with an ice cold mortar and pestle in cold water. Then, the homogenate was centrifuged at $1000 \mathrm{~g}$ for 10 minutes, the residue was washed three times with $10 \mathrm{~mL}$ of $80 \%$ ethanol and once with $10 \mathrm{~mL}$ of ethanol:chloroform mixture $(1: 1, \mathrm{v} / \mathrm{v})$. The residue was then washed with 10 $\mathrm{mL}$ of acetone, dried, and ashed. Boron concentration in cell wall was then measured in ashed samples as previously reported $[12,16]$ using the Azomethine- $\mathrm{H}$ method [43].

\subsection{Determination of Lignin in Seed Coat}

Lignin concentration in seed coat was measured as previously described [39,45]. Briefly, seeds were immersed in water for 12 hours, and then seed coat was removed from the cotyledon. The seed coat was dried for $16 \mathrm{~h}$ at $105^{\circ} \mathrm{C}$, and then placed in a desiccator at room temperature to cool. A weight of $250 \mathrm{mg}$ of dry seed coat was homogenized in $7 \mathrm{~mL}$ of $50 \mathrm{mM}$ potassium phosphate buffer at $\mathrm{pH}$ 7.0. The mixture was transferred into a centrifuge tube, and the homogenates were centrifuged at $1400 \mathrm{~g}$ for $10 \mathrm{~min}$. The pellet was washed and then centrifuged twice with $7 \mathrm{~mL}$ phosphate buffer $\mathrm{pH}$ 7.0; $3 \mathrm{X}$ with $7 \mathrm{~mL}$ of $1 \%(\mathrm{v} / \mathrm{v})$ Triton $\mathrm{X}-100$ in $\mathrm{pH} 7.0$ buffer; $2 \mathrm{X}$ with $7 \mathrm{~mL}$ of $1 \mathrm{M} \mathrm{NaCl}$ in $\mathrm{pH} 7.0$ buffer; $2 \mathrm{X}$ with 7 $\mathrm{mL}$ distilled water; and $2 \mathrm{X}$ with $5 \mathrm{~mL}$ acetone. The pellet was then placed in an oven to dry for $24 \mathrm{~h}$ at $60^{\circ} \mathrm{C}$ after 
which the pellet was placed into a vacuum desiccator to cool. The dry matter, which was considered as a proteinfree cell wall fraction, was placed in a centrifuge tube containing a reaction mixture of $1.2 \mathrm{~mL}$ of thioglycolic acid with $6 \mathrm{~mL} 2 \mathrm{M} \mathrm{HCl}$. The mixture was then heated on hot plate at $95^{\circ} \mathrm{C}$ for $4 \mathrm{~h}$, then placed at room temperature to cool, and the samples were centrifuged at $1400 \mathrm{~g}$ for 5 minutes, and the supernatant was discarded. The pellet containing the complex lignin-thioglycolic acid (LTGA) was washed $3 \mathrm{X}$ with $7 \mathrm{~mL}$ of distilled water, and the LTGA was extracted by shaking at $30^{\circ} \mathrm{C}$ for $18 \mathrm{~h}$ in $6 \mathrm{~mL} 0.5 \mathrm{M} \mathrm{NaOH}$. The supernatant was centrifugated at $1400 \mathrm{~g}$ for 5 minutes, and then stored. The pellet was washed again with $3 \mathrm{~mL} 0.5 \mathrm{M} \mathrm{NaOH}$ and mixed with the supernatant. The combined alkali extracts were acidified with $1.8 \mathrm{~mL}$ concentrated $\mathrm{HCl}$. The precipitation was obtained at $\left(0^{\circ} \mathrm{C}\right.$ for $\left.4 \mathrm{~h}\right)$, and LTGA was recovered by centrifugation the mixture at $1400 \mathrm{~g}$ for 5 minutes and washed $2 \mathrm{X}$ with $7 \mathrm{~mL}$ of distilled water. The pellet was dried at $60^{\circ} \mathrm{C}$, dissolved in $10 \mathrm{~mL} 0.5 \mathrm{M} \mathrm{NaOH}$, and the insoluble material was removed by centrifugation. Lignin concentrations were measured by reading the absorbance of the supernatant at $280 \mathrm{~nm}$ using a Beckman Coulter DU 800 spectrophotometer (Fullerton, California). Lignin concentrations were expressed as mg LTGA/g dry weight.

\subsection{Determination of Total Phenol Concentration}

The concentration of total phenol was measured as previously described [46] with modification [47] using a Folin-Ciocalteu assay and gallic acid standard. A weight of $0.5 \mathrm{~g}$ ground seed was extracted twice with $10 \mathrm{~mL}$ acetone/water $(50: 50, \mathrm{v} / \mathrm{v})$, and then $200 \mu \mathrm{L}$ seed extract and $1 \mathrm{~mL}$ of Folin-Ciocalteu reagent were mixed. One $\mathrm{mL} 20 \% \mathrm{Na}_{2} \mathrm{CO}_{3}$ aqueous solution was added and made to $5 \mathrm{ml}$ with distilled water. The color development was achieved by incubating the mixture for 90 minutes at room temperature. The concentration of total phenol was obtained by reading the absorbance at $765 \mathrm{~nm}$ using a Beckman Coulter DU 800 spectrophotometer (Fullerton, California). The total phenol concentration was expressed as mg GAE per $100 \mathrm{~g}$ of sample (mg GAE/100g).

\subsection{Isoflavones Analysis}

Concentrations of isoflavones daidzein, genistein, and glycitein were measured similar to those previously described $[48,49]$ using near-infrared (NIR) reflectance diode array feed analyzer (Perten, Springfield, IL, USA). Initial calibration equations were developed by Perten company and University of Minnesota, using Thermo Galactic Grams PLS IQ. The concentrations of isoflavo- nes were based on dry matter.

\subsection{Analysis of Seed Sucrose, Raffinose, and Stachyose}

Concentrations of sucrose, raffinose, and stachyose were measured in R8 seed. About $25 \mathrm{~g}$ seed were ground using a Laboratory Mill 3600 (Perten, Springfield, IL). Seed sugar concentrations were conducted using near infrared reflectance (NIR) according to others [3,50]. Near infrared reflectance was AD 7200 array feed analyzer (Perten, Springfield, IL). Initial calibrations equations were developed by the Department of Agronomy and Plant Genetics, University of Minnesota St Paul, MN, using Thermo Galactic Grams PLS IQ software, developed by Perten company (Perten, Springfield, IL). Analyses of sugars were based on seed dry matter.

\subsection{Experimental Design and Statistical Analysis}

Treatments were arranged in a split plot design with irrigation as a main block and B treatment as sub-plot. The data were subjected to analysis of variance using Proc GLM in SAS [51]. Means were separated by Fisher's least significant difference test at the $5 \%$ level of probability. Since the analysis of variance showed that there were interactions between the experiment 1 and experiment 2 for the measured variables, the data of each experiment were separately analyzed and presented in experiment 1 and experiment 2 .

\section{Results}

\subsection{Seed Phenol, Lignin, Isoflavones, and Boron}

The concentrations of total phenol and lignin in seed grown in WS and WSB were higher than in W and WB (Table 1). Total B concentration was higher in seed from W and WB than in seed from WS or WSB (Table 1). Cell wall boron percentage was higher in WS than in $\mathrm{WSB}, \mathrm{WB}$, or W. The concentration of individual or total seed isoflavones was higher in W and WB than in WS or WSB (Table 1). This trend was consistent in experiment 1 and 2 (Tables 1 and 2).

Applying foliar B fertilizer at R5 - R6 resulted in similar trend to those when foliar B was applied at R1 - R2 (Tables 2 and 3). However, the concentration of total B was higher when foliar B was applied at R5 - R6 than those when B was applied at R1 - R2. Cell wall B concentration was lower in WB than in W, WS, or WSB (Table 3). The general trend of the seed components in experiment 1 was similar to those in experiment 2 (Tables 3 and 4). Applying B at either R1 - R2 or R5 - R6 growth stages did not result in obvious differences in total phenol, lignin, or isoflavones concentrations. 
Table 1. Experiment 1, effect of foliar boron (B) fertilizer application at R1 - R2 (flowering stage) on total phenol, lignin, total $B$, cell wall $B$, and composition and total isoflavones in soybean seed. Boron was applied at R1 and R2 stages. Lignin was measured in seed coat. Foliar $B$ treatments were: $W=$ plants were watered with no foliar $B$; $W B$ = plants were watered and received foliar B; WS = plants were water-stressed with no foliar B; WSB = plants were water-stressed and received foliar $\mathbf{B}^{(*)}$.

\begin{tabular}{cccccccccc}
\hline Treatments & $\begin{array}{c}\text { Total phenol } \\
(\mathrm{g} / 100 \mathrm{~g})\end{array}$ & $\begin{array}{c}\text { Lignin } \\
(\mathrm{mg} \mathrm{GAE} / \mathrm{g})\end{array}$ & $\begin{array}{c}\text { Total B } \\
(\mathrm{mg} / \mathrm{kg})\end{array}$ & $\begin{array}{c}\text { Cell Wall B } \\
(\mathrm{mg} / \mathrm{kg})\end{array}$ & $\begin{array}{c}\text { Cell wall B } \\
(\%)\end{array}$ & $\begin{array}{c}\text { Daidzein } \\
(\mu \mathrm{g} / \mathrm{g})\end{array}$ & $\begin{array}{c}\text { Genistein } \\
(\mu \mathrm{g} / \mathrm{g})\end{array}$ & $\begin{array}{c}\text { Glycitein } \\
(\mu \mathrm{g} / \mathrm{g})\end{array}$ & $\begin{array}{c}\text { Total isoflavones } \\
(\mu \mathrm{g} / \mathrm{g})\end{array}$ \\
\hline $\mathrm{W}$ & $5.7 \mathrm{~b}$ & $4.5 \mathrm{c}$ & $43 \mathrm{~b}$ & $34 \mathrm{~b}$ & $79 \mathrm{~b}$ & $743 \mathrm{~b}$ & $675 \mathrm{~b}$ & $213 \mathrm{a}$ & $1631 \mathrm{~b}$ \\
$\mathrm{WB}$ & $5.5 \mathrm{~b}$ & $5.0 \mathrm{~b}$ & $46 \mathrm{a}$ & $37 \mathrm{a}$ & $80 \mathrm{~b}$ & $803 \mathrm{a}$ & $865 \mathrm{a}$ & $198 \mathrm{a}$ & $1866 \mathrm{a}$ \\
$\mathrm{WS}$ & $8.9 \mathrm{a}$ & $7.5 \mathrm{a}$ & $21 \mathrm{~d}$ & $19 \mathrm{~d}$ & $90 \mathrm{a}$ & $435 \mathrm{~d}$ & $412 \mathrm{~d}$ & $133 \mathrm{~b}$ & $980 \mathrm{~d}$ \\
$\mathrm{WSB}$ & $7.2 \mathrm{a}$ & $7.4 \mathrm{a}$ & $29 \mathrm{c}$ & $23 \mathrm{c}$ & $79 \mathrm{~b}$ & $542 \mathrm{c}$ & $498 \mathrm{c}$ & $122 \mathrm{~b}$ & $1162 \mathrm{c}$ \\
\hline
\end{tabular}

*Means within a column followed by the same letter are not significantly different at the $5 \%$ level.

Table 2. Experiment 2, effect of foliar boron (B) fertilizer application at R1 - R2 (flowering stage) on total phenol, lignin, total $B$, cell wall $B$, and composition and total isoflavones in soybean seed. Boron was applied at R1 and R2 stages. Lignin was measured in seed coat. Foliar $B$ treatments were: $W=$ plants were watered with no foliar $B$; $W B$ = plants were watered and received foliar B; WS = plants were water-stressed with no foliar B; WSB = plants were water-stressed and received foliar $\mathbf{B}^{(*)}$.

\begin{tabular}{cccccccccc}
\hline Treatments & $\begin{array}{c}\text { Total phenol } \\
(\mathrm{g} / 100 \mathrm{~g})\end{array}$ & $\begin{array}{c}\text { Lignin } \\
(\mathrm{mg} \mathrm{GAE} / \mathrm{g})\end{array}$ & $\begin{array}{c}\text { Total B } \\
(\mathrm{mg} / \mathrm{kg})\end{array}$ & $\begin{array}{c}\text { Cell Wall B } \\
(\mathrm{mg} / \mathrm{kg})\end{array}$ & $\begin{array}{c}\text { Cell wall B } \\
(\%)\end{array}$ & $\begin{array}{c}\text { Daidzein } \\
(\mu \mathrm{g} / \mathrm{g})\end{array}$ & $\begin{array}{c}\text { Genistein } \\
(\mu \mathrm{g} / \mathrm{g})\end{array}$ & $\begin{array}{c}\text { Glycitein } \\
(\mu \mathrm{g} / \mathrm{g})\end{array}$ & $\begin{array}{c}\text { Total isoflavones } \\
(\mu \mathrm{g} / \mathrm{g})\end{array}$ \\
\hline $\mathrm{W}$ & $4.6 \mathrm{c}$ & $5.7 \mathrm{~d}$ & $38 \mathrm{a}$ & $25 \mathrm{a}$ & $66 \mathrm{c}$ & $765 \mathrm{~b}$ & $854 \mathrm{~b}$ & $734 \mathrm{~b}$ & $2353 \mathrm{~b}$ \\
$\mathrm{WB}$ & $4.1 \mathrm{~d}$ & $6.3 \mathrm{c}$ & $36 \mathrm{a}$ & $24 \mathrm{a}$ & $67 \mathrm{c}$ & $812 \mathrm{a}$ & $971 \mathrm{a}$ & $882 \mathrm{a}$ & $2665 \mathrm{a}$ \\
$\mathrm{WS}$ & $8.5 \mathrm{a}$ & $9.6 \mathrm{~b}$ & $17 \mathrm{c}$ & $16 \mathrm{c}$ & $94 \mathrm{a}$ & $436 \mathrm{~d}$ & $465 \mathrm{~d}$ & $423 \mathrm{~d}$ & $1324 \mathrm{~d}$ \\
$\mathrm{WSB}$ & $7.3 \mathrm{~b}$ & $10.5 \mathrm{a}$ & $25 \mathrm{~b}$ & $20 \mathrm{~b}$ & $80 \mathrm{~b}$ & $557 \mathrm{c}$ & $543 \mathrm{c}$ & $643 \mathrm{c}$ & $1743 \mathrm{c}$ \\
\hline
\end{tabular}

*Means within a column followed by the same letter are not significantly different at the $5 \%$ level.

Table 3. Experiment 1, effect of foliar boron (B) fertilizer application at R5 - R6 (seed-fill stage) on total phenol, lignin, total boron (B), cell wall B, and composition and total isoflavones in soybean seed. Lignin was measured in seed coat. Foliar B fertilizer was applied at R5 and R6. Foliar B treatments were: $W=$ plants were watered with no foliar B; WB = plants were watered and received foliar B; WS = plants were water-stressed with no foliar B; WSB = plants were water-stressed and received foliar $\mathbf{B}^{(*)}$.

\begin{tabular}{|c|c|c|c|c|c|c|c|c|c|}
\hline Treatments & $\begin{array}{l}\text { Total phenol } \\
(\mathrm{g} / 100 \mathrm{~g})\end{array}$ & $\begin{array}{c}\text { Lignin } \\
\text { (mg GAE/g) }\end{array}$ & $\begin{array}{l}\text { Soluble B } \\
(\mathrm{mg} / \mathrm{kg})\end{array}$ & $\begin{array}{l}\text { Cell Wall B } \\
(\mathrm{mg} / \mathrm{kg})\end{array}$ & $\begin{array}{c}\text { Cell wall B } \\
(\%)\end{array}$ & $\begin{array}{l}\text { Daidzein } \\
(\mu \mathrm{g} / \mathrm{g})\end{array}$ & $\begin{array}{l}\text { Genistein } \\
(\mu \mathrm{g} / \mathrm{g})\end{array}$ & $\begin{array}{l}\text { Glycitein } \\
(\mu \mathrm{g} / \mathrm{g})\end{array}$ & $\begin{array}{c}\text { Total isoflavones } \\
(\mu \mathrm{g} / \mathrm{g})\end{array}$ \\
\hline $\mathrm{W}$ & $6.7 \mathrm{c}$ & $7.6 \mathrm{c}$ & $48 \mathrm{a}$ & $38 \mathrm{a}$ & $79 \mathrm{~b}$ & $857 \mathrm{~b}$ & $754 \mathrm{~b}$ & $265 \mathrm{a}$ & $1876 \mathrm{~b}$ \\
\hline WS & $8.5 \mathrm{a}$ & $10.4 \mathrm{~b}$ & $28 \mathrm{c}$ & $25 \mathrm{c}$ & 89 a & $467 \mathrm{~d}$ & $378 \mathrm{~d}$ & $114 \mathrm{~d}$ & $959 \mathrm{~d}$ \\
\hline WSB & $7.9 \mathrm{~b}$ & $11.1 \mathrm{a}$ & $33 \mathrm{~b}$ & $30 \mathrm{~b}$ & $91 \mathrm{a}$ & $576 \mathrm{c}$ & $532 \mathrm{c}$ & $156 \mathrm{c}$ & $1264 \mathrm{c}$ \\
\hline
\end{tabular}

*Means within a column for each water treatment separately followed by the same letter are not significantly different at the $5 \%$ level.

Table 4. Experiment 2, effect of foliar boron (B) fertilizer application at R5 - R6 (seed-fill stage) on total phenol, lignin, total boron (B), cell wall B, and composition and total isoflavones in soybean seed. Lignin was measured in seed coat. Foliar B fertilizer was applied at R5 and R6. Foliar B treatments were: $W=$ plants were watered with no foliar B; WB = plants were watered and received foliar B; WS = plants were water-stressed with no foliar B; WSB = plants were water-stressed and received foliar $\mathbf{B}^{(*)}$.

\begin{tabular}{|c|c|c|c|c|c|c|c|c|c|}
\hline Treatments & $\begin{array}{l}\text { Total phenol } \\
(\mathrm{g} / 100 \mathrm{~g})\end{array}$ & $\begin{array}{c}\text { Lignin } \\
\text { (mg GAE/g) }\end{array}$ & $\begin{array}{l}\text { Soluble B } \\
(\mathrm{mg} / \mathrm{kg})\end{array}$ & $\begin{array}{l}\text { Cell Wall B } \\
(\mathrm{mg} / \mathrm{kg})\end{array}$ & $\begin{array}{c}\text { Cell wall B } \\
(\%)\end{array}$ & $\begin{array}{l}\text { Daidzein } \\
(\mu \mathrm{g} / \mathrm{g})\end{array}$ & $\begin{array}{l}\text { Genistein } \\
(\mu \mathrm{g} / \mathrm{g})\end{array}$ & $\begin{array}{l}\text { Glycitein } \\
(\mu \mathrm{g} / \mathrm{g})\end{array}$ & $\begin{array}{c}\text { Total isoflavones } \\
(\mu \mathrm{g} / \mathrm{g})\end{array}$ \\
\hline $\mathrm{W}$ & $5.4 \mathrm{c}$ & $5.4 \mathrm{~d}$ & $50 \mathrm{a}$ & $39 \mathrm{a}$ & $78 \mathrm{c}$ & $765 \mathrm{~b}$ & $865 \mathrm{~b}$ & $234 \mathrm{~b}$ & $1864 \mathrm{~b}$ \\
\hline WB & $4.3 \mathrm{~d}$ & $6.3 \mathrm{c}$ & $52 \mathrm{a}$ & $36 \mathrm{~b}$ & $69 \mathrm{~d}$ & $848 \mathrm{a}$ & $978 \mathrm{a}$ & $287 \mathrm{a}$ & $2113 \mathrm{a}$ \\
\hline WS & $8.7 \mathrm{a}$ & $11.3 \mathrm{a}$ & $21 \mathrm{c}$ & $17 \mathrm{~d}$ & $81 \mathrm{~b}$ & $365 \mathrm{~d}$ & $310 \mathrm{~d}$ & $111 \mathrm{c}$ & $786 \mathrm{~d}$ \\
\hline WSB & $7.5 \mathrm{~b}$ & $9.3 \mathrm{~b}$ & $31 \mathrm{~b}$ & $27 \mathrm{c}$ & $87 \mathrm{a}$ & $552 \mathrm{c}$ & $425 \mathrm{c}$ & $104 \mathrm{c}$ & $1081 \mathrm{c}$ \\
\hline
\end{tabular}

${ }^{*}$ Means within a column for each water treatment separately followed by the same letter are not significantly different at the $5 \%$ level. 


\subsection{Seed Sucrose, Raffinose, Stachyose, and Total Sugars}

Application of foliar boron at R1 - R2 or R5 - R6 resulted in higher seed sucrose concentration in $\mathrm{W}$ and $\mathrm{WB}$ than in WS or WSB (Tables 5-8). However, seed raffinose and stachyose concentrations in W and WB were lower than in WS or WSB (Tables 5-8). Seed sucrose was higher in WSB than in WS, but raffinose and stachyose were higher in WS than in WSB. No consis- tency of total sugar concentrations was noticed between foliar B treatments. This trend was also observed when foliar B fertilizer was applied at R5-R6, but with noticeable increase in sucrose concentration when foliar B was applied at R5 - R6 (Tables 7-8). The increase in sucrose concentration resulted from foliar B at R1-R2 (Tables

Table 5. Experiment 1, effect of foliar boron (B) fertilizer application at R1 - R2 (flowering stage) on seed concentrations of sucrose, raffinose, stachyose, and combined sugars (sucrose + raffinose + stachyose) in soybean seed. Foliar B was applied at R1 and R2. Foliar $B$ treatments were: $\mathrm{W}=$ plants were watered with no foliar $B ; \mathrm{WB}=$ plants were watered and received foliar $B$; WS = plants were waterstressed with no foliar B; WSB = plants were water-stressed and received foliar $\mathbf{B}^{(*)}$.

\begin{tabular}{ccccc}
\hline Treatments & $\begin{array}{c}\text { Sucrose } \\
(\mathrm{mg} / \mathrm{g})\end{array}$ & $\begin{array}{c}\text { Raffinose } \\
(\mathrm{mg} / \mathrm{g})\end{array}$ & $\begin{array}{c}\text { Stachyose } \\
(\mathrm{mg} / \mathrm{g})\end{array}$ & $\begin{array}{c}\text { Total sugars } \\
(\mathrm{mg} / \mathrm{g})\end{array}$ \\
\hline $\mathrm{W}$ & $47 \mathrm{~b}$ & $5.7 \mathrm{c}$ & $36 \mathrm{~d}$ & $88.7 \mathrm{~b}$ \\
$\mathrm{WB}$ & $53 \mathrm{a}$ & $6.3 \mathrm{~b}$ & $39 \mathrm{c}$ & $98.3 \mathrm{a}$ \\
$\mathrm{WS}$ & $32 \mathrm{~d}$ & $7.2 \mathrm{a}$ & $43 \mathrm{~b}$ & $82.2 \mathrm{c}$ \\
WSB & $43 \mathrm{c}$ & $6.2 \mathrm{~b}$ & $48 \mathrm{a}$ & $97.2 \mathrm{a}$ \\
\hline
\end{tabular}

*Means within a column for each water treatment separately followed by the same letter are not significantly different at the $5 \%$ level.

Table 6. Experiment 2, effect of foliar boron (B) fertilizer application at R1 - R2 (flowering stage) on seed concentrations of sucrose, raffinose, stachyose, and combined sugars (sucrose + raffinose + stachyose) in soybean seed. Foliar B was applied at R1 and R2. Foliar $B$ treatments were: $W=$ plants were watered with no foliar $B ; \mathbf{W B}=$ plants were watered and received foliar B; WS = plants were waterstressed with no foliar B; WSB = plants were water-stressed and received foliar $\mathbf{B}^{(*)}$.

\begin{tabular}{ccccc}
\hline Treatments & $\begin{array}{c}\text { Sucrose } \\
(\mathrm{mg} / \mathrm{g})\end{array}$ & $\begin{array}{c}\text { Raffinose } \\
(\mathrm{mg} / \mathrm{g})\end{array}$ & $\begin{array}{c}\text { Stachyose } \\
(\mathrm{mg} / \mathrm{g})\end{array}$ & $\begin{array}{c}\text { Total sugars } \\
(\mathrm{mg} / \mathrm{g})\end{array}$ \\
\hline $\mathrm{W}$ & $41 \mathrm{~b}$ & $4.3 \mathrm{~d}$ & $35 \mathrm{~d}$ & $80.3 \mathrm{c}$ \\
$\mathrm{WB}$ & $54 \mathrm{a}$ & $5.3 \mathrm{c}$ & $39 \mathrm{c}$ & $98.3 \mathrm{a}$ \\
$\mathrm{WS}$ & $23 \mathrm{~d}$ & $8.5 \mathrm{a}$ & $57 \mathrm{a}$ & $88.5 \mathrm{~b}$ \\
WSB & $35 \mathrm{c}$ & $7.2 \mathrm{~b}$ & $43 \mathrm{~b}$ & $85.2 \mathrm{cb}$ \\
\hline
\end{tabular}

*Means within a column for each water treatment separately followed by the same letter are not significantly different at the $5 \%$ level.
Table 7. Experiment 1, effect of foliar boron (B) fertilizer application at R5 - R6 (seed-fill stage) on seed concentrations of sucrose, raffinose, stachyose, and combined sugars (sucrose + raffinose + stachyose) in soybean seed. Foliar B was applied at R5 and R6. Foliar $B$ treatments were: $\mathrm{W}=$ plants were watered with no foliar $B$; $W B=$ plants were watered and received foliar $B$; WS = plants were waterstressed with no foliar B; WSB = plants were water-stressed and received foliar $\mathbf{B}^{(*)}$.

\begin{tabular}{ccccc}
\hline Treatments & $\begin{array}{c}\text { Sucrose } \\
(\mathrm{mg} / \mathrm{g})\end{array}$ & $\begin{array}{c}\text { Raffinose } \\
(\mathrm{mg} / \mathrm{g})\end{array}$ & $\begin{array}{c}\text { Stachyose } \\
(\mathrm{mg} / \mathrm{g})\end{array}$ & $\begin{array}{c}\text { Total sugars } \\
(\mathrm{mg} / \mathrm{g})\end{array}$ \\
\hline $\mathrm{W}$ & $55 \mathrm{~b}$ & $4.6 \mathrm{~d}$ & $33 \mathrm{~d}$ & $92.6 \mathrm{~b}$ \\
$\mathrm{WB}$ & $69 \mathrm{a}$ & $6.3 \mathrm{c}$ & $36 \mathrm{c}$ & $111.3 \mathrm{a}$ \\
$\mathrm{WS}$ & $29 \mathrm{~d}$ & $8.5 \mathrm{a}$ & $58 \mathrm{a}$ & $95.5 \mathrm{~b}$ \\
$\mathrm{WSB}$ & $37 \mathrm{c}$ & $7.2 \mathrm{~b}$ & $51 \mathrm{~b}$ & $95.2 \mathrm{~b}$ \\
\hline
\end{tabular}

*Means within a column for each water treatment separately followed by the same letter are not significantly different at the $5 \%$ level.

Table 8. Experiment 2, effect of foliar boron (B) fertilizer application at R5-R6 (seed-fill stage) on seed concentrations of sucrose, raffinose, stachyose, and combined sugars (sucrose + raffinose + stachyose) in soybean seed. Foliar B was applied at R5 and R6. Foliar $B$ treatments were: $W$ = plants were watered with no foliar B; WB = plants were watered and received foliar $B$; WS = plants were water-stressed with no foliar B; WSB = plants were water-stressed and received foliar $\mathbf{B}^{(*)}$.

\begin{tabular}{ccccc}
\hline Treatments & $\begin{array}{c}\text { Sucrose } \\
(\mathrm{mg} / \mathrm{g})\end{array}$ & $\begin{array}{c}\text { Raffinose } \\
(\mathrm{mg} / \mathrm{g})\end{array}$ & $\begin{array}{c}\text { Stachyose } \\
(\mathrm{mg} / \mathrm{g})\end{array}$ & $\begin{array}{c}\text { Total sugars } \\
(\mathrm{mg} / \mathrm{g})\end{array}$ \\
\hline $\mathrm{W}$ & $56 \mathrm{~b}$ & $4.7 \mathrm{c}$ & $31 \mathrm{c}$ & $91.7 \mathrm{~b}$ \\
$\mathrm{WB}$ & $67 \mathrm{a}$ & $3.1 \mathrm{~d}$ & $33 \mathrm{c}$ & $103.1 \mathrm{a}$ \\
$\mathrm{WS}$ & $26 \mathrm{~d}$ & $9.8 \mathrm{a}$ & $63 \mathrm{a}$ & $98.8 \mathrm{a}$ \\
WSB & $33 \mathrm{c}$ & $8.5 \mathrm{~b}$ & $49 \mathrm{~b}$ & $90.5 \mathrm{~b}$ \\
\hline
\end{tabular}

* Means within a column for each water treatment separately followed by the same letter are not significantly different at the $5 \%$ level.

5-6) or R5 - R6 (Tables 7-8) supports previous findings that $\mathrm{B}$ is involved in carbohydrate metabolism. The opposite trend between sucrose and raffinose and stachyose in WS and WSB compared with W and WB suggested that water stress altered the distribution and biosynthesis of sucrose, raffinose, and stachyose concentrations, and indicated a possible role of raffinose and stachyose in water stress tolerance.

\section{Discussion}

\subsection{Lignin, Phenol, and Boron}

The increase of seed phenol and lignin in WS and WSB than in W or WB when foliar B was applied at R1 - R2 or R5 - R6 indicated that water stress resulted in an increase in seed phenol and lignin concentrations. It was 
reported that B was associated with the content and metabolism of phenolic compounds [52]. This was explained that the accumulation of phenolic compounds was due to increased synthesis of phenolic compounds and inhibition of phenolic compounds use in the cell wall synthesis in B deficient tissues [53]. Results from leaf tissue showed that B in WS and WSB was the lowest (18 $\mathrm{mg} \mathrm{B} / \mathrm{kg}$ for WS and $27 \mathrm{mg} / \mathrm{kg}$ for WSB) compared with $47 \mathrm{mg} / \mathrm{kg}$ for $\mathrm{W}$ and $62 \mathrm{mg} / \mathrm{kg}$ for WB) (data not shown). Based on these results, the level of B in leaf tissue in WS and WSB was below adequate, especially in WS plants. Therefore, one can predict that both WS and WSB plants were grown under B deficiency and both phenol and lignin concentrations were expected to be higher, and the increase in phenol and lignin concentration could be due to both water stress and B deficiency. It was reported that B plays a significant role in transport of carbohydrates, cell wall metabolism [22], permeability and stability of cell membranes [10], phenol metabolism, and lignin biosynthesis $(11,54)$. It was shown that $\mathrm{B}$ deficiency induced plasma membrane solute leakage $[20,55]$, inhibited meristematic tissue development [11], and affected cell wall integrity [21]. Other researchers found that at the early stage of water stress $(0-14 \mathrm{~d})$, the activity of some enzymes involved in lignin biosynthesis such as phenyl alanine ammonialyase and ascorbate peroxidase increased. However, other enzymes such as guaiacol peroxidase, coniferyl alcohol peroxidase and syringal- dazine peroxidase exhibited greater activity during the final stages of stress (14 - $28 \mathrm{~d}$ ) [41]. The increase of phenol and lignin concentrations under water stress may provide WS and WSB plants with rigidity and resistance against mechanical damage [56] to protect the root sys- tem against water stress.

From the biochemical and physiological aspect, the increase of phenol and lignin concentrations can be discussed in the following manner. Boron has the ability to form complexes with compounds having cis-diol configurations in the cell wall and plasma membranes, and plays a crucial role in the maintenance of structural integrity of plasma membranes, possibly to protect plasma membranes against peroxidative damage by toxic oxygen species [57]. It is widely accepted that the morphological and physiological disturbances caused by boron deficiency, in our case resulting from water stress in WS and WSB, could be associated with formation of complexes between $\mathrm{B}$ and compounds having cis-hydroxly groups (diols) such as pectin in cell walls, glycoproteins or glycolipids in membranes, and $o$-diphenols [11]. It was found that $\mathrm{B}$ deficiency resulted in increased phenolic compounds and polyphenoloxidase activity, leading to ion leakage, phenols oxidation and generation of reactive quinones which produce toxic oxygen species leading to a peroxidative damage to cell components such as membrane lipids and proteins [57]. Moreover, in B-deficient tissues, defense capacity of species could be weakened due to reduced levels of ascorbic acid, SH-compounds, and $\mathrm{H}_{2} \mathrm{O}_{2}$ scavenging enzymes [58,59]. Therefore, the damaging effect of water stress was due to its effects on its inhibitory effects on B uptake, transport, and accumulation, resulting in B-deficient plants grown in WS and WSB.

The other possibility is that B deficiency, resulting from water stress, increased levels of toxic oxygen species due to impairments in photosynthesis and antioxidative defense systems, leading to a shift in the substrate flux from glycolysis into the pentose phosphate pathway, enhancing phenol synthesis [22] and the formation of borate complexes with some phenolics such caffeic acid. This borate-complex, resulting from B-caffeic acid, can block the formation of quinones, facilitating the synthesis of phenolic alcohols which are the precursors of lignin biosynthesis [10,54]. Therefore, formation of B-complexes with phenolics would increase both phenol and lignin concentrations, and this is may be important for the membrane integrity [57] and cell wall structural support against the damaging effects of water stress.

The increase of total seed $\mathrm{B}$ in W and WB compared to WS and WSB was due to irrigation and foliar B fertilizer. The higher cell wall percentage in WS and WSB than in W or WB was due to limited available/soluble B in the cell and to the higher cell wall $\mathrm{B}$ fraction due to the structural role of $\mathrm{B}$. The opposite trend between total $\mathrm{B}$ and cell wall $\mathrm{B}$ can be explained by more total boron is available in the cell, the less cell wall B is used for cell wall structural support. Since B in WS and WSB plants was deficient, the B available to the cell for other function such as phenolics and carbohydrate metabolism was limited. Since the primary function of B is structural, then the limited available B will be integrated into cell wall synthesis. Our findings are supported by previous results $[16,21,57,60]$ in that $B$ has a structural role. Although the involvement of $\mathrm{B}$ in phenol and lignin metabolism is supported by previous research [11], the physiological and biochemical mechanisms that control the relationships between $\mathrm{B}$ and phenolics biosynthesis need further research.

\subsection{Isoflavones}

The increase of individual and total isoflavones under foliar B application in seed from W and WB plants suggested that both irrigation and B has a stimulatory effect on isoflavones biosynthesis, and this may suggest a possible involvement of B in isoflavones synthesis. Boron is involved in several physiological, biochemical, and mo- 
lecular processes such as sugar transport and metabolism, cell wall structure, lignification, RNA metabolism, phenol metabolism, membrane integrity [61], ascorbate metabolism [58], and oxygen activation [11]. Recent research showed that foliar B fertilizer altered protein, oil, and fatty acids [16], and B was involved in cell wall integrity and synthesis by formation of boron-pectin complexes $[60,62,63]$ and plasma membrane integrity $[57,64$, 65]. Whether the involvement of $B$ in isoflavones is direct or indirect remains unclear. From the gene expression aspect, water stress was found to affect the expression of genes. For example, it was found that the expression pattern of these genes were clustered in three categories: 1) genes that were expressed at low level at the beginning of seed development, peaked at intermediate, and decreased at the late stages (PAL1, CHS1, CHS2, $C H S 3$, and $C H S 4$ genes); 2) genes that were expressed at higher level at early stages, then decreased at the end of seed maturation $(F 3 H, C 4 H, C H I B 1, D F R 1, C H R$, and $4 C L$ genes); and 3) genes that gradually increased their expression, reaching their maximum expression level by the late stages (GST24, CHS7, CHS8, IFS1, and IFS2 genes). Transcripts of $C H I 1 A$ showed a unique expression pattern, and were considered a distinct group. Other researchers found that synthesis and accumulation of isoflavones were affected by irrigation, and irrigation increased isoflavones by 2.5 folds $[66,67]$.

It was concluded that soil moisture increased daidzein, genistein and total isoflavones, but not glycitein when water stress was imposed at R6 [68]. Up to 45\% increase of isoflavones was measured under irrigated conditions versus nonirrigated conditions [67]. In these two experiments cultivars responded differently to irrigation, and in both experiments an increased expression of $P A L, C H S 7$, CHS8 and IFS2 temporally coincided with the onset of embryonic isoflavonoid accumulation [33]. The content and distribution of isoflavones were found to be altered by cultivar, tissue type, and growth conditions such as planting location, crop year, temperature, soil nutrition, and storage durations [69-71]. Other researchers did not find differences in isoflavones between irrigated and nonirrigated environments [72], but the discrepancies in the results were due to uncontrollable natural rainfall [72] and differences in the effects of environmental factors [24].

\subsection{Sucrose, Raffinose, Stachyose, and Total Sugars}

The increase of sucrose concentration in seed grown in $\mathrm{W}$ and WB compared to those from WS and WSB indicated that irrigation and $\mathrm{B}$ application increased seed sucrose accumulation. The opposite trend between su- crose and raffinose and stachyose, observed in WS and WSB was previously observed, and the involvement of B in sugars was previously reported [11]. The relationship between sugar fractions was also previously reported. For example, a positive correlation between total sugar and sucrose and raffinose was found, but no significant correlation was found for stachyose $[2,73,74]$. It was also reported that a positive correlation was found between sucrose and raffinose, but a negative correlation was found between sucrose and stachyose [75]. Soybean genotypes with a unique oligosaccharide profile with higher sucrose and low raffinose and stachyose were identified in soybean plant introductions [74], but no soybean cultivars with improved sugar profiles have been released [74]. Our results showed that foliar B fertilizer resulted in higher seed sucrose under irrigated conditions, but under water stress conditions, the concentrations of seed sucrose decreased and seed raffinose and stachyose increased. Application of foliar B at either R - R2 or R5 - R6 did not result in obvious differences in total sugars under irrigated or non-irrigated conditions, suggesting that B application under irrigated or non-irrigated may mainly affect the partitioning of sugars. Although the involvement of B in sugars was previously reported, the mechanisms that control this relationship are not yet understood, and further research is needed to investigate this relationship.

\section{Conclusion}

Seed phenol and lignin concentrations were higher under water-stressed soybean than in those of watered plants whether foliar B was applied or not, or whether foliar B was applied at R1 - R2 or at R5 - R6. Foliar B fertilizer resulted in higher total seed $\mathrm{B}$ and isoflavones under watered and water-stressed plants. Cell wall B had the opposite trend to that of total $\mathrm{B}$, supporting previous research that $\mathrm{B}$ has a structural role, but a metabolic role of B cannot be excluded. Foliar B fertilizer application resulted in an increase of seed sucrose under irrigated conditions but a decrease in raffinose and stachyose under water stress conditions, suggesting that water stress altered the portioning of sugars. Higher seed isoflavones and sucrose are desirable, and have nutritional benefits to the consumer. Although higher stachyose may contribute to water stress/drought tolerance, stachyose has negative effects on the nutritive value of the soy meal and causes flatulence or diarrhea in nonruminants because it is indigestible by human and animals.

\section{Acknowledgements}

We thank Sandra Mosley for lab technical assistance and seed composition analyses. 


\section{REFERENCES}

[1] R. F. Wilson, "Seed Composition," In: H. R. Boerma and J. E Specht, Eds., Soybeans: Improvement, Production, and Uses, American Society of Agronomy, Inc., Madison, 2004, pp. 621-668.

[2] T. Hymowitz and F. I. Collins, "Variability of Sugar Content of Seed of Glycine $\max (\mathrm{L}$.) Merr. and G. soja Serb. and Zucco," Agronomy Journal, Vol. 66, No. 2, 1974, pp. 239-240.

doi:10.2134/agronj1974.00021962006600020017x

[3] N. Bellaloui, J. R. Smith, A. M. Gillen and J. D. Ray, "Effect of Maturity on Seed Sugar in the Early Soybean Production System as Measured on Near-Isogenic Soybean Lines," Crop Science, Vol. 49, No. 2, 2009, pp. 608620. doi:10.2135/cropsci2008.04.0192

[4] N. Bellaloui, J. R. Smith, A. M. Gillen and J. D. Ray, "Effects of Maturity, Genotypic Background, and Temperature on Seed Mineral Composition in Near-Isogenic Soybean Lines in the Early Soybean Production System," Crop Science, Vol. 51, No. 3, 2011, pp. 1161-1171. doi:10.2135/cropsci2010.04.0187

[5] S. R. Schnebly and W. R. Fehr, "Effect of Years and Planting Dates on Fatty Acid Composition of Soybean Genotypes," Crop Science, Vol. 33, No. 4, 1993, pp. 716719. doi:10.2135/cropsci1993.0011183X003300040016x

[6] G. Sakthivelu, M. K. A. Devi, P. Giridhar, T. Rajasekaran, G. A. Ravishankar, M. T. Nikolova, G. B. Angelov, R. M. Todorova and G. P. Kosturkova, "Isoflavone Composition, Phenol Content, and Antioxidant Activity of Soybean Seeds from India and Bulgaria," Journal of Agricultural and Food Chemistry, Vol. 56, No. 6, 2008, pp. 2090-2095. doi:10.1021/jf072939a

[7] M. Messina, "Modern Applications for an Ancient Bean: Soybeans and the Prevention and Treatment of Chronic Disease," Journal of Nutrition, Vol. 125, 1995, pp. 567569.

[8] S. M. Potter, J. A. Baum, H. Y. Teng, R. J. Stillman, N. F. Shay and J. W. Erdman, "Soy Protein and Isoflavones: Their Effects on Blood Lipids and Bone Density in Postmenopausal Women," American Journal of Clinical Nutrition, Vol. 68, 1998, pp. 1375s-1379s.

[9] Wikipedia, Natural Phenology. http://en.wikipedia.org/wiki/Natural_phenolverified11-17 $-2011$.

[10] D. J. Pilbeam and E. A. Kirkby, "The Physiological Role of Boron in Plants," Journal of Plant Nutrition, Vol. 6, No. 7, 1983, pp. 563-582. doi:10.1080/01904168309363126

[11] H. Marschner, "Mineral Nutrition of Higher Plants," Academic Press, San Diego, 1995, pp. 379-396.

[12] C. Dordas, "Foliar Boron Application Improves Seed Set, Seed Yield, and Seed Quality of Alfalfa," Agronomy Journal, Vol. 98, No. 4, 2006, pp. 907-913. doi:10.2134/agronj2005.0353

[13] C. Dordas, G. E. Apostolides and O. Goundra, "Boron Application Affects Seed Yield and Seed Quality of Sugar Beets," Journal of Agricultural Sciences, Vol. 145,
No. 4, 2007, pp. 377-384. doi:10.1017/S0021859607006879

[14] H. M. Rawson and R. N. Noppakoonwong, "Sterility in Wheat in Subtropical Asia Extent, Causes and Solutions," In: H. M. Rawson and K. D. Subedi, Eds., Proceedings of Workshop, Nepal ACIAR, Canberra, 1996, pp. 85-89.

[15] H. M. Rawson, "The Developmental Stage during Which Boron Limitation Causes Sterility in Wheat Genotypes and the Recovery of Fertility," Australian Journal of Plant Physiology, Vol. 23, No. 6, 1996, pp. 709-717. doi:10.1071/PP9960709

[16] N. Bellaloui, K. N. Reddy, A. M. Gillen and C. A. Able, "Nitrogen Metabolism and Seed Composition as Influenced by Foliar B Application in Soybean," Plant and Soil, Vol. 336, No. 1-2, 2010, pp. 143-155. doi:10.1007/s11104-010-0455-6

[17] J. F. Jackson, et al., "Current Topics in Plant Biochemistry and Physiology," University of Missouri Press, Columbia, 1991.

[18] A. Asad, F. P. C. Blamey and D. G. Edwards, "Effects of Boron Foliar Applications on Vegetative and Reproductive Growth of Sunflower," Annals of Botany, Vol. 92, No. 4, 2003, pp. 565-570. doi:10.1093/aob/mcg179

[19] N. Roth-Bejerano and C. C. Ltai, "Effect of Boron on Stomatal Opening in Epidermal Strips of Commelina Comunis," Plant Physiology, Vol. 52, No. 2, 1981, pp. 302-304. doi:10.1111/j.1399-3054.1981.tb08510.x

[20] P. M. Tang and R. K. de la Fuente, "Boron and Calcium Sites Involved in Indole-3-Acetic Acid Transport in Sunflower Hypocotyl Segments," Plant Physiology, Vol. 81, No. 2, 1986, pp. 651-655. doi:10.1104/pp.81.2.651

[21] H. Hu and P. H. Brown, "Localization of Boron in Cell Walls of Squash and Tobacco and its Association with Pectin: Evidence for a Structural Role of Boron in the Cell Wall," Plant Physiology, Vol. 105, 1994, pp. 681689.

[22] W. M. Dugger, "Boron in Plant Metabolism," In: A. Lauchli and R. L. Beileski, Eds., Encylopedia of Plant Physiology, Springer Verlag, Berlin, Vol. 15B, 1983, pp. 626-650.

[23] R. A. Dixon, "Isoflavonoids: Biochemistry, Molecular Biology and Biological Functions," Elsevier, Amsterdam, 1993, pp. 773-823.

[24] Y. Wang, M. Hamburger, J. Gueho and K. Hostettmann, "Antimicrobial Flavonoids from Psiadia trinervia and their Methylated and Acetylated Derivatives," Phytochemistry, Vol. 28, No. 9, 1989, pp. 2323-2327. doi:10.1016/S0031-9422(00)97976-7

[25] M. M. Parvez, K. Tomita-Yokotani, Y. Fujii, T. Konishi and T. Iwashina, "Effects of Quercetin and Its Seven Derivatives on the Growth of Arabidopsis thaliana and Neurospora crassa," Biochemistry System Ecology, Vol. 32, No. 7, 2004, pp. 631-635. doi:10.1016/j.bse.2003.12.002

[26] V. Lattanzio, M. Veronica, T. Lattanzio and A. Cardinali, "Role of Phenolics in the Resistance Mechanisms of Plants against Fungal Pathogens and Insects," In: F. Im- 
perato, Ed., Phytochemistry: Advances in Research, Research Signpost, Kerala, 2006, pp. 23-67.

[27] A. R. Knaggs, "The Biosynthesis of Shikimate Metabolites," Natural Product Reports, Vol. 18, No. 3, 2001, pp. 334-355. doi:10.1016/j.bse.2003.12.002

[28] T. Aoki, T. Akashi, and S. Ayabe, "Flavonoids of Leguminous Plants Structure, Biological Activity, and Biosynthesis," Journal of Plant Research, Vol. 113, 2008, p. 475.

[29] D. A. Whiting, "Natural Phenolic Compounds 1900-2000: A Bird's Eye View of a Century's Chemistry," Natural Production Report, Vol. 18, 2000, pp. 583-606.

[30] K. L. Fritz, C. M. Seppanen, M. S. Kurzer and A. S. Csallany, "The in Vivo Antioxidant Activity of Soybean Isoflavones in Human Subjects," Nutrition Research, Vol. 23, No. 4, 2003, pp. 479-487. doi:10.1016/S0271-5317(03)00005-8

[31] A. P. Wickens, "Ageing and the Free Radical Theory," Respiratory Physiology, Vol. 128, No. 3, 1994, pp. 379391. doi:10.1016/S0034-5687(01)00313-9

[32] O. Yu and B. McGonigle, "Metabolic Engineering of Isoflavone Biosynthesis," Advances in Agronomy, Vol. 86, 2005, pp. 147-190. doi:10.1016/S0065-2113(05)86003-1

[33] S. Dhaubhadel, M. Gijzen, P. Moy and M. Farhangkhoee, "Transcriptome Analysis Reveals a Critical Role of CHS7 and CHS8 Genes for Isoflavonoid Synthesis in Soybean Seeds," Plant Physiology, Vol. 143, No. 1, 2007, pp. 326338. doi:10.1104/pp.106.086306

[34] T. Akashi, T. Aoki and S. Ayabe, "Cloning and Functional Expression of a Cytochrome P450 cDNA Encoding 2-hydroxyisoflavanone Synthase Involved in Biosynthesis of the Isoflavonoid Skeleton in Licorice," Plant Physiology, Vol. 121, No. 3, 1999, pp. 821-828. doi:10.1104/pp.121.3.821

[35] C. L. Steele, M. Gijzen, D. Qutob and R. A. Dixon, "Molecular Characterization of the Enzyme Catalyzing the Aryl Migration Reaction of Isoflavonoid Biosynthesis in Soybean," Archives in Biochemistry and Biophysics, Vol. 367, No. 1, 1999, pp. 146-150. doi:10.1006/abbi.1999.1238

[36] W. Jung, O. Yu, S. C. Lau, D. P. O'Keefe, J. Odell and G. Fader, "Identification and Expression of Isoflavone Synthase, the Key Enzyme for Biosynthesis of Isoflavones in Legumes," National Biotechnology, Vol. 18, 2000, pp. 208-212. doi:10.1038/72671

[37] L. Fan, R. Linker, S. Gepstein, E. Tanimoto, R. Yamamoto and P. M. Neumann, "Progressive Inhibition by Water Deficit of Cell Wall Extensibility and Growth Along the Elongation Zone of Maize Roots is Related to Increased Lignin Metabolism and Progressive Stelar Accumulation of Wall Phenolics," Plant Physiology, Vol. 140, No. 2, 2006, pp. 603-612. doi:10.1104/pp. 105.073130

[38] D. Vincent, C. Lapierre, B. Pollet, G. Cornic, L. Negroni and M. Zivy, "Water Deficits Affect Caffeate $O$-methyltransferase, Lignification, and Related Enzymes in Maize
Leaves. A Proteomic Ivestigation," Plant Physiology, Vol. 137, No. 3, 2005, pp. 949-960.

doi:10.1104/pp.104.050815

[39] P. J. C. Alvarez, F. C. Krzyzanowski, J. M. G. Mandarino and J. B. Franca-Neto, "Relationship between Soybean Seed Coat Lignin Content and Resistance to Mechanical Damage," Seed Science and Technology, No. 25, 1997, pp. 209-214.

[40] K. Yoshimura, A. Masuda, M. Kuwano, A. Yokota and K. Akashi, "Programmed Proteome Response for Drought Avoidance/Tolerance in the Root of a C-3 Xerophyte (Wild Watermelon) Under Water Deficits," Plant Cell Physiology, Vol. 49, No. 2, 2008, pp. 226-241.

doi: $10.1093 / \mathrm{pcp} / \mathrm{pcm} 180$

[41] L. Bok-Rye, K. Kil-Yong, J. Woo-Jin, A. Jean-Christophe, O. Alain and K. Tae-Hwan, "Peroxidases and Lignification in Relation to the Intensity of Water-deficit Stress in White Clover (Trifolium repens L.)," Journal of Experimental Botany, Vol. 58, No. 6, 2007, pp. 12711279. doi: $10.1093 / \mathrm{jxb} / \mathrm{erl} 280$

[42] W. R. Fehr, C. E. Caviness, D. T. Burmood and J. S. Pennington, "Stage of Development Descriptions for Soybeans, Glycine max (L.) Merrill," Crop Science, Vol. 11, No. 6, 1971, pp. 929-931. doi:10.2135/cropsci1971.0011183X001100060051x

[43] G, Lohse, "Microanalytical Azomethine-H Method for Boron Determination in Plant Tissue," Communications in Soil Science and Plant, Vol. 13, No. 2, 1982, pp. 127-134. doi:10.1080/00103628209367251

[44] M. K. John, H. H. Chuah and J. H. Neufeld, "Application of Improved Azomethine-H Method to the Determination of Boron in Soils and Plants," Analytical Letters, Vol. 8, No. 8, 1975, pp. 559-568. doi: $10.1080 / 00032717508058240$

[45] F. C. Krzyzanowski, J. B. Franca-Neto, J. M. G. Mandarino and M. Kaster, "Comparison between two Gravimetric Methods to Determine the Lignin Content in Soybean Seed Coat," Seed Science and Technology, No. 29, 2001, pp. 619-624.

[46] V. L. Singleton and J. A. Rossi, "Colorimetry of Total Phenolic with Phosphomolybdic-Phosphotungstic Acid Reagents," American Journal of Enology and Viticulture, Vol. 16, 1965, pp. 44-158.

[47] B. J. Xu and S. K. C. Chang "A Comparative Study on Phenolic Profiles and Antioxidant Activities of Legumes as Affected by Extraction Solvents," Journal of Food Science, Vol. 72, No. 2, 2007, pp. S159-S166. doi:10.1111/j.1750-3841.2006.00260.x

[48] M. J. Morrison, E. R. Cober, M. F. Saleem, N. B. McLaughlin, J. Fregeau-Reid, B. L. Ma, W. Yan and L. Woodrow, "Changes in Isoflavone Concentration with 58 Years of Genetic Improvement of Short-Season Soybean Cultivars in Canada," Crop Science, Vol. 48, No. 6, 2008, pp. 2201-2208. doi:10.2135/cropsci2008.01.0023

[49] T. Sato, K. Eguchi, T. Hatano and Y. Nishiba, "Use of Near-Infra Red Reflectance spectroscopy for the Estimation of Isoflavone Contents of Soybean Seeds," Plant 
Production Science, Vol. 11, No. 4, 2008, pp. 481-486. doi:10.1626/pps.11.481

[50] J. R. Wilcox and R. M. Shibles, "Interrelationships among Seed Quality Attributes in Soybean," Crop Science, Vol. 41, No. 1, 2001, pp. 11-14. doi:10.2135/cropsci2001.41111x

[51] SAS, "SAS 9.1 TS Level 1M3, Windows Version 5.1.2600," SAS Institute, Cary, 2001.

[52] J. M. Ruiz, G. Bretones, M. Baghour, A. Belakbir and L. Romero, "Relationship between Boron and Phenolic Metabolism in Tobacco Leaves," Phytochemistry, Vol. 48, No. 2, 1998, pp. 269-272. doi:10.1016/S0031-9422(97)01132-1

[53] J. M. Ruiz, P. C. Garcia, R. M. Rivero and L. Romero, "Response of Phenolic Metabolism to the Application of Carbendazim Plus Boron in Tobacco," Physiologia Plantarum, Vol. 106, No. 2, 1999, pp. 151-157. doi:10.1034/j.1399-3054.1999.106201.x

[54] D. H. Lewis, "Boron, Lignification and the Origin of Vascular Plants-A Unified Hypothesis," New Phytologist, Vol. 84, No. 2, 1980, pp. 209-229. doi:10.1111/j.1469-8137.1980.tb04423.x

[55] D. G. Blevins and K. M. Lukaszewski, "Boron in Plant Structure and Function," Annual Review of Plant Physiology and Plant Molecular Biology, Vol. 49, 1998, pp. 481-500. doi:10.1146/annurev.arplant.49.1.481

[56] J. P. Ride, "Cell Wall and other Structural Barriers in Defence," In: J. A. Callow, Ed., Biochemical Plant Pathology, John Wiley \& Sons, Ltd., Hoboken, 1983, pp. 215-235.

[57] I. Cakmak and V. Romheld, "Boron Deficiency-induced Impairments of Cellular Functions in Plants," Plant and Soil, Vol. 193, No. 1-2, 1997, pp. 71-83. doi:10.1023/A:1004259808322

[58] K. M. Lukaszewski nad D. G. Blevins, "Root Growth Inhibition in Boron-deficient or Aluminium-Stressed Squash May Be a Result of Impaired Ascorbate Metabolism," Plant Physiol, Vol. 112, 1996, pp. 1135-1140.

[59] J. J. L. Cilliers and V. L. Singleton, "Autoxidative Phenolic Ring Opening under Alkaline Conditions as a Model for Natural Polyphenols in Food," Journal of Agriculture and Food Chemistry, Vol. 38, No. 9, 1990, pp. 1797-1798. doi:10.1021/jf00099a003

[60] N. Bellaloui and P. H. Brown, "Cultivar Differences in Boron Uptake and Distribution in Celery (Apium graveolens), Tomato (Lycopersicon esculentum) and Wheat (Triticum aestivum)," Plant and Soil, Vol. 198, No. 2, 1998, pp. 153-158. doi:10.1023/A:1004343031242

[61] J. Parr and M. J. C. Rhodes, "Natural Plant Defense Mechanisms," In: L. G. Copping, Ed., Protection Agents from Nature, Royal Society of Chemistry Education, London, 1996.

[62] H. Hu, P. H. Brown and J. M. Labavitch, "Species Variability in Boron Requirement is Correlated with Cell Wall Pectin," Journal of Experimental Botany, Vol. 47, No. 2, 1996, pp. 227-232. doi:10.1093/jxb/47.2.227

[63] T. Matoh, "Boron in Plant Cell Walls," Plant and Soil,
Vol. 193, No. 1-2, 1997, pp. 59-70. doi:10.1023/A:1004207824251

[64] I. Cakmak, H. Kurz and H. Marschner, "Short-Term Effects of Boron, Germanium, and High Light Intensity on Membrane Permeability in Boron Deficient Leaves of Sunflower," Physiologia Plantarum, Vol. 95, No. 1, 1995, pp. 11-18. doi:10.1111/j.1399-3054.1995.tb00801.x

[65] P. H. Brown, N. Bellaloui, M. A. Wimmer, E. S. Bassil, J. Ruiz, H. Hu, H. Pfeffer, F. Dannel and V. Romheld, "Boron in Plant Biology," Plant Biology, Vol. 4, No. 2, 2002, pp. 205-223. doi:10.1055/s-2002-25740

[66] J. O. Bennett, O. Yu, L. G. Heatherly and H. B. Krishna, "Accumulation of Genistein and Daidzein, Soybean Isoflavones Implicated in Promoting Human Health, Is Significantly Elevated by Irrigation," Journal of Agriculture and Food Chemistry, Vol. 52, No. 25, 2004, pp. 7574-7579. doi:10.1021/jf049133k

[67] A. M. Al-Tawaha, P. Seguin, D. L. Smith and R. B. Bonnell, "Irrigation Level Affects Isoflavone Concentrations of Early Maturing Soya Bean Cultivars," Journal of Agronomy and Crop Science, Vol. 193, No. 4, 2007, pp. 238-246. doi:10.1111/j.1439-037X.2007.00263.x

[68] V. V. Lozovaya, A. V. Lygin, A. V. Ulanov, R. L. Nelson, J. Dayde and A. M. Widholm, "Effect of Temperature and Soil Moisture Status during Seed Development on Soybean Seed Isoflavone Concentration and Composition," Crop Science, Vol. 45, No. 5, 2005, pp. 1934-1940. doi:10.2135/cropsci2004.0567

[69] S. J. Lee, J. K. Ahn, S. H. Kim, J. T. Kim, S. J. Han and M. Y. Jung, "Variation in Isoflavone of Soybean Cultivars with Location and Storage Duration," Journal of Agriculture and Food Chemistry, Vol. 51, 2003, pp. 3383-3389.

[70] S. J. Lee, W. K. Yan, J. K. Ahn, I. M. Chung, "Effects of Year, Site, Genotype and their Interactions on Various Soybean Isoflavones. Field Crop Research, Vol. 81, No. 2-3, 2003, pp. 181-192. doi:10.1016/S0378-4290(02)00220-4

[71] C. Tsukamoto, S. Shimada, K. Igita, S. Kudou, M. Kokubun, K. Okubo and K. Kitamura, "Factors Affecting Isoflavones Content in Soybean Seeds: Changes in Isoflavones, Saponins, and Composition of Fatty Acids at Different Temperatures during Seed Development," Journal of Agriculture Food Chemistry, Vol. 43, No. 5, 1995, pp. 1184-1192. doi:10.1021/jf00053a012

[72] J. J. Gutierrez-Gonzalez, S. K. Guttikonda, L.-S. P. Tran, D. L. Aldrich, R. Zhong, O. Yu, H. T. Nguyen and D. A. Sleper, "Differential Expression of Isoflavone Biosynthetic Genes in Soybean during Water Deficits," Plant Cell Physiology, Vol. 51, No. 6, 2010, pp. 936-948. doi:10.1093/pcp/pcq065

[73] U. A. Hartwig, C. A. Maxwell, C. M. Joseph and D. A. Phillips, "Chrysoeriol and Luteolin Released from Alfalfa Seeds Induce Nod Genes in Rhizobium meliloti," Plant Physiology, Vol. 92, No. 1, 1990, pp. 116-122. doi:10.1104/pp.92.1.116

[74] A. Hou, P. Chen, J. Alloatti, D. Li, L. Mozzoni, B. Zhang and A. Shi, "Genetic Variability of Seed Sugar Content in 
Worldwide Soybean Germplasm Collections," Crop Science, Vol. 49, No. 3, 2009, pp. 903-912. doi:10.2135/cropsci2008.05.0256

[75] A. S. Malik, O. Boyko, N. Atkar and W. F. Young, “A
Comparative Study of MR Imaging Profile of Titanium Pedicle Screws," Acta Radiologica, Vol. 42, No. 3, 2001, pp. 291-293. doi:10.1080/028418501127346846 